\title{
A NATUREZA JURÍDICA DO PARQUET ESPECIAL
}

\author{
UBERGUE RIBEIRO JUNIOR*
}

1) Considerações preliminares. - 2) Introdução e exposição do problema. - 3) Principais vertentes doutrinárias. - 3.1) Ministério Público Especial vinculado ao Ministério Público da União. - 3.2) Ministério Público Especial como parte da estrutura interna do Tribunal de Contas. - 3.3) Ministério Público Especial incorporado ao Ministério Público dos Estados. - 4) Natureza jurídica e assento constitucional do Ministério Público Especial. Posição adotada. - 5) Diretrizes constitucionais para uma nova interpretação do art. 130 da Constituição Federal - 6) Ministério Público Especial autônomo. Novas perspectivas. - 7) Conclusão.

\section{1) Considerações preliminares}

O nosso tempo já não é mais nosso. Enquanto estamos procurando qualificar o tempo, dando-lhe um atributo, uma qualidade pessoal, ele se encarrega de mostrar que não nos pertence. Na verdade, nunca pertenceu. A fábula de encarcerar o tempo como algo "nosso" não encontra mais qualquer razão para existir. Por tal motivo, e dentro de uma perspectiva ilusória, vê-se que o "nosso tempo" nada mais é do que o tempo que temos de transformar a ciência, a arte, e por que não, a vida.

Se o homem abnega-se desse poder transformador, ele passa a renunciar o "seu tempo", e o tempo em que vive torna-se apenas a maneira mais fácil de se ligar dois pontos. Se o tempo nos marca de maneira tão indelével, com sinais e impressões no corpo e na alma, o mínimo que podemos fazer é não nos deixar levar por essa falta de poder transformador, e assim, nos mais variados campos da atividade humana, buscarmos as vias de transformação do tempo, ou pelo menos, do "nosso tempo".

A melhor tradução dessa relação dual tempo x transformação é a nossa própria época. Com a crescente complexidade das relações sociais, mudam-se os conceitos,

* Advogado da União em Brasília, e Ex-Assessor Especial da Procuradoria Geral do Ministério Público junto ao Tribunal de Contas do Rio Grande do Norte.

R. Dir. Adm.,

Rio de Janeiro, 236: 129-161,

Abr./Jun. 2004 
as expectativas, os costumes, e após o turbilhão de acontecimentos do último século, o homem parece cada vez mais perdido, rendendo, finalmente, o seu verdadeiro espírito transformador ao quadro de inovações desordenadas do mundo moderno.

Esta época, pois, não passa de mais uma extensão da condição paradoxal do ser humano. Enquanto somos capazes de avançar na Medicina e nas tecnologias, transformando aspectos exógenos como, por exemplo, mais informação, conforto, modernidade etc., retroagimos mais e mais em relação a nós mesmos e aos nossos pares, ou seja, apesar de vivermos grandes arroubos tecnológicos, nosso espírito humanístico transformador permanece hiberno, dormente, fadado, talvez, ao esquecimento dos que dormem ou dos que não sabem mais quando vão acordar.

Toda esta situação fática que se constata na vida de um modo geral termina por se estender também às Ciências Humanas, e, dentro delas, ao Direito. A constante e frenética busca pela informação especializada parece haver retirado, deste último, sua natureza de conhecimento humanístico. O pragmatismo da chamada "vida moderna" vem conclamando a todos que o importante é preocupar-se com assuntos da hora, com matérias que tenham por objeto um dado concreto de expressões econômicas imediatas. As especialidades sucedem às humanidades, não que uma exclua a outra, mas é inegável que, hodiernamente, ambas tomam direções distintas.

Não obstante tais constatações, algumas proposições legislativas que tratam de modificações em institutos jurídicos, e que adentram ao ordenamento pátrio com o propósito de "renovação", muitas vezes parecem representar um inegável retrocesso em detrimento aos avanços já conquistados pela sociedade brasileira. Um bom exemplo disso está nas mudanças relacionadas à propositura das chamadas ações de improbidade administrativa, alterações estas, que seguramente, trouxeram muito mais recuos do que aperfeiçoamentos técnicos.

O que é mais preocupante, é que este tipo de retrocesso ocorre numa área como a ação de improbidade administrativa, que junto com o Código de Defesa do Consumidor, denota um dos progressos mais extraordinários do direito pátrio, posto que, ambos, lidam com parcelas, segmentos da sociedade e frações de uma elite que até pouco tempo se achava intocável: os agentes políticos e os grandes grupos econômicos.

Com efeito, este pequeno retrato, irrisório fragmento de distorções existentes no mundo jurídico, constitui, como dito acima, o natural reflexo - no Direito das más interpretações que o homem faz na vida.

Dentro de todo esse panorama marcado por distorções e excessos pragmáticos, temas jurídicos que lidam com uma perspectiva mais abstrata ficam relegados a um segundo plano, ainda que esta primeira diretriz filosófica, possa a vir repercutir diretamente no universo concreto das relações jurídicas.

Nessa diretiva, tal esquecimento fica mais evidenciado quando essas especulações doutrinárias de caráter abstrato terminam em discussões sobre a defesa da moralidade administrativa, a correção de atos e práticas administrativas distorcidas, o combate à corrupção, a malversação de recursos públicos, enfim, quando conduzem à transformação, "nesse tempo", de mecanismos de controle da Administração Pública. 
Assim, é justamente com um espírito quase quixotesco de resgate desse ânimo transformador, de não se render à dificuldade de temas que precisam ser redefinidos em sua dimensão exegética, que se traz, nessa oportunidade, um ponto de discussão considerado dos mais "dormentes" de toda a doutrina brasileira: A Natureza Jurídica do Parquet Especial, e, a partir dela, a proposta de releitura de seu assento constitucional, atribuições e papel institucional.

Através desse estudo, procurou-se examinar a posição constitucional do Ministério Público junto ao Tribunal de Contas face à Constituição Federal de 1988, as correntes doutrinárias e suas adaptações classificatórias, os caminhos para uma nova interpretação constitucional, a investigação em torno de sua real natureza jurídica, até alcançar, finalmente, uma nova perspectiva para um Parquet Especial mais atuante, e, via de consequiência, mais transformador de seu próprio tempo.

Estudar a fonte é descobrir a razão, examinar a natureza é revelar o ser. Por conseguinte, sabendo-se o que uma coisa $\dot{e}$, descobre-se o que ela pode fazer. Este, portanto, é o propósito desta obra, e por que não dizer, a motivação da busca por um espírito transformador.

\section{2) Introdução e exposição do problema}

O Ministério Público junto ao Tribunal de Contas, Ministério Público Especial (MPE)' ou Parquet Especial, sempre trouxe infindáveis dúvidas, discussões e controvérsias a respeito de sua natureza, organização e limites de competência.

Apesar de, como dito, constituir uma das matérias mais latentes de toda a doutrina brasileira, o Parquet Especial é hoje um gigante adormecido. Fala-se assim, porque talvez não tenha ele se apercebido da extensão de seus limites, de sua responsabilidade institucional e, principalmente, de seu maior trunfo: é, sem sombra de dúvidas, o melhor observatório da Administração Pública.

Diz-se o melhor, não porque tenha um quadro mais capacitado do que outra instituição, mas sim, porque está localizado de forma estratégica, atuando e interferindo diretamente no cotidiano da Administração Pública, como um órgão livre e independente da hierarquização administrativa e de todas as ordenações verticais do Estado.

No entanto, apesar de o MPE permanecer posicionado legitimamente neste posto, neste espaço de atuação privilegiada, é evidente que há - dentro das mais variadas fontes jurídicas - uma espécie de resistência a inspirar tapumes e barreiras na atuação desse Parquet, chegando alguns, em muitos casos, a questionar até mesmo sua própria natureza de Ministério Público.

Traduzindo, ao invés de existir um esforço concentrado para redefinir e estender atribuições a mais um órgão de controle, independente e estrategicamente posicionado, trazendo assim benesses incomensuráveis para toda a sociedade nessa longa e desigual luta contra a imoralidade administrativa, procura-se deixá-lo ao rol dos esquecidos, como uma esdrúxula espécie de "poder" que não pode.

1 Designação que se utilizará, doravante, para exprimir o Ministério Público Especial. 
A Revelação máxima dessa posição privilegiada está determinada pela manifestação de sua própria competência institucional. Como se sabe, a competência desse Parquet é delimitada pela competência dos Tribunais de Contas, posto que, materialmente, é mesma encartada no artigo 71 da Constituição Federal.

Numa simples e perfunctória análise desse dispositivo, vê-se que as Cortes de Contas, e, por conseguinte, o Ministério Público que atua perante elas, exercem um controle quase total dos atos administrativos oriundos da Administração Pública Direta e Indireta. Isto é, todas as despesas, prestações de contas, pensões, aposentadorias, licitações, convênios, contratos, pagamentos, suprimento de fundos, denúncias etc., passam pelo crivo desse Ministério Público, que bebe o conhecimento diretamente da fonte, e no momento em que está acontecendo o erro ou a malversação nos quadros públicos, privilégio este, que os Ministérios Públicos da União e dos Estados, infelizmente não possuem.

De qualquer modo, dentro de todo esse raciocínio, parece que o grande desafio que a doutrina tem pela frente é exatamente transformar o melhor observatório da Administração Pública, no melhor executor da verdadeira aplicação do princípio da moralidade administrativa em todas as suas consequências. Reduzindo a termos simplórios, é trocar, o simples "ver", pelo "ver" e "poder agir", até onde for necessário para elidir o dolo e o erro, afastando assim, o pejorativo "poder" que não pode.

Ainda que correndo o risco das sempre perigosas metáforas, se uma torre à frente de uma grande fortaleza é sempre o melhor observatório para se vislumbrar as táticas beligerantes do inimigo, certamente também o será para as primeiras medidas de combate face a esse mesmo adverso.

Passando-se a considerar essa situação como um dado factual incontestável, e, conseqûentemente, a reconhecer o poder e até mesmo o dever de agir dessa torre de observação nas questões de defesa da integridade do referido forte e de seus integrantes, não se pode, de igual modo, negar que, sendo o Parquet Especial essa torre avançada de observação, não possa ele defender e agir pragmaticamente contra os malfeitores da Administração Pública e da sociedade, considerados aqui, respectivamente, como a fortaleza e seus integrantes.

Aquele que vê melhor pode agir melhor e mais eficazmente. E quando esse que vê melhor é um órgão do Ministério Público, ainda que seja o polêmico MPE, não lhe pode ser defeso tomar certas medidas para assegurar o cumprimento dos principios constitucionais da Administração Pública, até porque, ele atıa perante os Tribunais de Contas, mas não exclusivamente perante estes.

Tal aspecto é primordial nesta obra. A partir do momento que se reconhece o Parquet Especial como um Ministério Público autônomo, conjugado constitucionalmente com o Ministério Público da União e dos Estados, e formando com estes, uma trinca de atuação ministerial na defesa da ordem jurídica, do regime democrático e dos interesses sociais e individuais indisponíveis, abre-se para aquele mesmo Parquet toda uma nova perspectiva institucional de atuação e responsabilidade, inclusive, com acesso ao Poder Judiciário, nas medidas que sejam necessárias para o cumprimento da lei e da moralidade administrativa, quando não houver mais meios de assegurá-las no âmbito da Corte de Contas em que atua. 
Com isto, não se quer instaurar a balbúrdia institucional de competências, mas sim, apenas registrar que sendo o Ministério Público junto ao Tribunal de Contas - do modo como está posto na Constituição Federal de 1988, através dos artigos $73, \S 2^{\circ}$, inciso I, e 130 - indubitavelmente "Ministério Público", não pode o mesmo sofrer o pesado ônus da ilegitimidade, sendo sumariamente descartado de uma relação jurídica processual, apenas por ter seu campo primeiro de atuação perante os Tribunais de Contas.

Estas são, portanto, as linhas mestras que alimentam a controvérsia doutrinária, ou seja, ser ou não ser um Ministério Público no mesmo patamar constitucional do Ministério Público da União e dos Estados, e, dentro dessa racionalidade constitucional, até onde pode ir no exercício de suas atividades ministeriais.

Entretanto, para que ele possa ter a dimensão real de suas iniciativas, precisa saber quem é, resolver seus problemas ontológicos, problemas do ser, para que, só a partir daí, possa encarar os problemas do que pode fazer.

\section{3) Principais vertentes doutrinárias}

A polêmica sempre trouxe, como característica indissociável, a diversidade. As controvérsias surgidas de toda e qualquer atividade dialética importam, muito mais que uma simples exposição de dessemelhanças, uma verdadeira riqueza cultural e intelectual. Neste conspecto, sabe-se que são justamente essas diferenças e desencontros na maneira de observar e julgar a realidade que fazem a ciência avançar.

Imbuído desse espírito de diversidade, o Direito é a própria materialização da diferença. É nele, acima de tudo, que se põe as expectativas dos opostos, sejam elas pragmáticas, advindas das partes de uma relação jurídica. sejam elas doutrinárias, decorrentes das opiniões dos doutos no aperfeiçoamento constante dos institutos jurídicos.

Nessa linha tradutora de dissimilitudes, o Ministério Público junto ao Tribunal de Contas encontra vasto campo de posições e controvérsias. Não é de hoje que se avultam as mais variadas teorias quando o assunto é a colocação institucional do Parquet Especial, e os critérios de interpretação constitucional que condicionam e legitimam essa colocação.

Dentro dessa perspectiva, dois caminhos surgiram com a proposta de enquadrar o MPE, como bem demonstra Alexandre de Moraes em sua Constituição do Brasil Interpretada: "Muito se discutiu sobre a configuração jurídico-institucional desse Ministério Público junto ao Tribunal de Contas da União, basicamente se estaria dentro da estrutura orgânica do Ministério Público da União e, conseqüentemente, sob a chefia do Procurador Geral da República, ou se estaria estruturalmente ligado ao próprio Tribunal de Contas da União, sem, portanto, qualquer vínculo com o Ministério Público da União".?

2 MORAES, Alexandre de. Constituição do Brasil Interpretada. São Paulo: Atlas, 2002, p. 1.581. 
De igual modo, ainda há aqueles, dentre os quais o próprio Alexandre de Moraes, que preferem sustentar a viabilidade de um MPE apenas no âmbito do Tribunal de Contas da União, restando, ao Ministério Público Estadual, todas as atribuições de atuar perante as Cortes de Contas dos respectivos Estados. Trocando em miúdos, significa dizer que, para esta teoria, ao menos no âmbito estadual, não existiria um Parquet Especial propriamente dito.

Sendo assim, expostas objetivamente as principais tendências do pensamento doutrinário no que tange ao modo de encarar o Ministério Público junto ao Tribunal de Contas, é preciso, nessa oportunidade, fazer um breve levantamento de seus propósitos conceituais, para que, a partir de um exercício dialético, possa-se, finalmente, extrair dos aspectos negativos de cada teoria, a raiz ôntica mais adequada para o MPE.

\section{1) Ministério Público especial vinculado ao Ministério Público da união}

Dentre todas as teorias que tentaram estabelecer a posição constitucional do Parquet Especial, esta parece ser a mais improvável. Não pela falta de lógica ou de fundamento, mas porque foi o próprio legislador constituinte que assim não quis.

Hugo Nigro MAZZILLI, uma das maiores autoridades quando o assunto é Ministério Público, relembra: "como já tivemos a oportunidade de sustentar $(O$ Ministério Público na Constituição..cit.), a propósito das ramificações do Ministério Público na Constituição da República, o Ministério Público junto ao Tribunal de Contas deixou de ser previsto como instituição própria, no art.127 (provavelmente art.128), tendo em vista a supressão da alínea " $e$ " do inciso I desse dispositivo, (...) (Ato Declaratório D-1.144, constituinte Ibsen Pinheiro, emenda 2t00452)".

Com efeito, se foi o próprio legislador constituinte que retirou o Ministério Público que atua junto ao Tribunal de Contas de um dos incisos que o faria integrante do Ministério Público da União (art.128, inciso I, alínea "e"), não há motivos para querer, agora, tentar enquadrá-lo como tal.

Partindo desta premissa, qualquer um mais vigilante poderia argüir: se o constituinte não queria o MPE como parte integrante do Ministério Público da União, por qual razão iria querê-lo como um órgão autônomo, na mesma linha de disposição e assento do Ministério Público da União e dos Estados? Ou seja, se não queria um minus (que era ser parte integrante de outro Ministério Público, in casu, o da União), por qual razão haveria de querer um plus (ser alçado ao mesmo destaque constitucional do Ministério Público da União e dos Estados)?

A resposta parece estar exatamente na conjugação do art. $73, \S 2^{\circ}$, inciso I, com art. 130 da Constituição Federal, pois nessa interminável polêmica, há de se considerar duas proposições essenciais: a uma, o legislador constituinte não quis o MPE como parte do Ministério Público da União, e, para isso, retirou-o, de forma incisiva 
do art.128; a duas, embora também (a princípio) não o quisesse como uma terceira via, ele o fez inserir de maneira expressa na Constituição Federal através de dois artigos específicos (art. $73, \S 2^{\circ}$, inciso I e art.130), fato este, que tornou sua postura extremamente paradoxal, dando assim, e ao contrário do art.128, margem a outras interpretações.

Isto quer dizer que por mais que se queira contestar a autonomia do MPE, não parece ser razoável querer enquadrá-lo dentro de uma suposta alínea " $e$ ", do inciso I, do art.128, até porque, essa alínea "e" só não existe, por vontade expressa do legislador.

Realmente, se o constituinte não queria o minus, ele não poderia, em tese, ter alcançado o plus. Mas o fato, é que isto aconteceu, e pela posição dos arts. $73, \S 2^{\circ}$, inciso I e 130. combinado com um exercício mais sistemático de interpretação com o art. 128, a partir do momento que se leva em conta aqueles dispositivos — da forma como estão - outro não poderia ser o desfecho, senão considerar o MPE como uma espécie de terceira via, conforme se verá mais adiante.

Assim, dizer que o MPE é parte integrante do Ministério Público da União, quando a própria Constituição expressamente suprimiu esta condição sem criar qualquer outro artigo que pudesse embasar tal hipótese (como, aliás, ocorreu com o art. 73 e 130), ou que este Ministério Público Especial deveria ser preenchido por membros da carreira do Ministério Público da União - v.g. Procuradores da República - é consagrar, de uma vez por todas, a existência de disposições completamente inúteis e sem sentido dentro da Constituição Federal, qual sejam, os arts. 73, $\S 2^{\circ}$, inciso $\mathrm{I}$, e 130 .

Por mais que este último preceito seja polêmico, mal redigido, confuso ou que adquira algum outro adjetivo nessa linha de qualidades, ele não pode ser tido como letra morta, ainda mais, sendo norma originária. Resumindo, é preciso fazer valer essa prescrição constitucional, dá-lhe utilidade, e isso, só poderá ser feito com o reconhecimento do MPE como órgão autônomo dentro das carreiras ministeriais.

Se a Carta Maior não quis o Ministério Público Especial como parte do Ministério Público da União, e se essa interpretação, fatalmente levaria tais artigos à pecha de inutilidade, então, por todos esses argumentos, não pode proceder a afirmativa de ser o MPE parte integrante do Ministério Público da União, seja na condição de uma ilusória alínea "e" do inciso I do art.128, seja como órgão a ser preenchido por membros deste último.

\section{2) Ministério Público especial como parte da estrutura interna do Tribunal de Contas}

A segunda opção mencionada refere-se ao enquadramento do MPE na intimidade estrutural do próprio Tribunal de Contas. Essa, aliás, foi a posição que predominou no Supremo Tribunal Federal: "O STF, decidindo essa relevante questão, entendeu que o Ministério Público, junto ao Tribunal de Contas da União, é instituição que não integra o Ministério Público da União, cujos ramos estão taxativamente inscritos no rol do art.128, inciso I, da Constituição Federal, declarando a 
constitucionalidade da referida lei por entender possível a vinculação administrativa desse Ministério Público ao próprio Tribunal de Contas da União". ${ }^{4}$

Examinando objetivamente esta maneira de encarar os fatos, a impressão que fica é a de que tal alternativa não passa de um mero paliativo. No meio de tanto embaraço doutrinário, situar o Ministério Público Especial como parte integrante da estrutura das Cortes de Contas soa como uma espécie de saída "conciliatória" (para se evitar o enfrentamento das verdadeiras questões ontológicas desse Ministério Público), e que não trouxe, nem de longe, uma resolução definitiva para os arts. 73 , $\S 2^{\circ}, \mathrm{I}$, e 130 da Constituição Federal.

E isso não é difícil de ser demonstrado. Se o MPE for vinculado apenas de forma administrativa aos Tribunais de Contas, o foco do problema restará desviado, pois em nenhum momento se estará discutindo a sua natureza como instituição, nem muito menos, o alcance da posição constitucional dada por aquelas disposições.

Por outro lado, se for reconhecido como parte do Tribunal de Contas, não apenas na esfera administrativa, mas sim, como órgão estrutural daquele, fica claro que se estará criando uma nova função para o Parquet, qual seja, a do Ministério Público doméstico, que faz apenas o dever de casa, de modo burocrático e de acordo com os interesses do tribunal, alijando completamente o seu verdadeiro papel.

Seja lá qual for a idéia que se tem de Ministério Público enquanto instituição, esta corrente, em que pese todo o respeito, definitivamente, não condiz e nem combina, com a autêntica e genuína função institucional de um órgão que tem o dever e a responsabilidade de defender toda a ordem jurídica, o regime democrático e os interesses sociais e individuais indisponíveis.

Como se percebe, é muita responsabilidade sobre ele para reduzi-lo a uma mera estrutura interna de um tribunal. Contudo, não se está, com isto, querendo dizer que o MPE não possa constar das Leis Orgânicas e Regimentos das Cortes de Contas. Ele pode, e até deve, ser previsto nessas ocasiões legiferantes no que se refere aos elementos básicos de seu exercício funcional perante o colegiado. O que não se pode concordar, é que um órgão que acima de tudo é Ministério Público (instituição dotada de unidade, indivisibilidade e independência funcional) seja jungido a uma condição de subordinação hierárquica e funcional, como se fosse uma diretoria ou uma procuradoria administrativa.

Ministério Público "que faz parte" de tribunal não pode ser Ministério Público, principalmente, quando se conhece a essência deste que foi um dos órgãos mais enaltecidos, na natureza de seu dever institucional, pelo texto constitucional de 1988.

Querer enquadrá-lo dessa maneira, além de ser incompatível com a Constituição Federal, é tentar criar uma nova espécie de Ministério Público que não pode existir. É comum se dizer, que a partir do instante em que o Ministério Público junto ao Tribunal de Contas for reconhecido como órgão autônomo se estará criando uma "nova" espécie de Ministério Público (o que não é verdade, até porque, ele está previsto em norma originária da Constituição, não tendo, portanto, nada de novo).

4 MORAES, Alexandre de. Constituição do Brasil Imterpretada. São Paulo: Atlas, 2002, p. 1.581. 
No entanto, basta inverter o ângulo de observação para se ter a plena certeza de que são justamente teses como essa (um Parquet como parte integrante de tribunal) que tentam criar uma nova, esdrúxula e improvável espécie de Ministério Público: "O Ministério Público como órgão de tribunal".

Nesse desiderato, mutatis mutandis, seria o mesmo que imaginar o Ministério Público dos Estados como "órgão do Tribunal de Justiça". Como é elementar, tal Parquet atua perante o Poder Judiciário e nem por isso torna-se parte integrante deste, o que se denota, conseqüentemente, que este critério não é satisfatório como fonte doutrinária na árdua investigação da natureza jurídica do MPE.

Assim, se esta assertiva parece ser tão absurda em relação ao Ministério Público dos Estados, também deve ser para o Ministério Público Especial nessa colocação de simples órgão da estrutura do Tribunal de Contas.

Como se verá neste estudo, o diferencial do MPE está apenas no funcionamento junto às Cortes de Contas e na delimitação de sua competência (que em substância é a mesma destes colegiados), no mais, ele é Ministério Público como qualquer outro, e sua natureza jurídica deve ser encontrada no próprio texto constitucional, assim como acontece com os demais Ministérios Públicos, e não, como parte integrante da estrutura de um tribunal. Até porque, não se pode chamar um órgão de Ministério Público e ao mesmo tempo tentar descaracterizá-lo como tal, retirando-lhe qualidades ou condições que dele são indissociáveis.

Dessa forma, subjugar qualquer instituição que receba a designação de Ministério Público a esse tipo de condição será, sempre, sob tal ponto de vista, uma maneira de fazer parecer menor uma instituição que é grande por sua própria natureza.

\section{3) Ministério Público especial incorporado ao Ministério Público dos estados}

Por derradeiro, a última corrente encontra seu ponto maior de fixação na seguinte idéia manifestada por Alexandre de MORAES: "Discordamos do posicionamento adotado pelo STF, em relação aos Ministérios Públicos que devem atuar junto aos Tribunais de Contas Estaduais, uma vez que a Constituição Federal somente consagra em nível estadual um único Ministério Público, uno e indivisível, e, diferentemente do previsto no art.73, $\S 2^{\circ}$, I, da CF em relação ao Tribunal da União, a Carta Maior não faz menção à existência de um Ministério Público junto aos Tribunais de Contas dos Estados".

Levando-se em conta um critério puramente objetivo de análise, essa posição parece esbarrar num ponto nuclear: o princípio da simetria. Ora, se existe tal princípio (e sua existência é pacífica em todas as fontes jurídicas), tornando obrigatório o mesmo modelo constitucional da União para os Estados na real condição de normas de repetição obrigatória, e, se por outro lado, junto ao Tribunal de Contas da União funciona um MPE, e não um Ministério Público da União (Ministério Público Federal, Ministério Público do Trabalho, Ministério Público Militar, Minis- 
tério Público do Distrito Federal e Territórios), por que se iria reconhecer para cada unidade da federação - que deve seguir o mesmo modelo constitucional - a legitimidade do Ministério Público dos Estados, quando não existe, para o Ministério Público da União, a mesma legitimidade?

Como se denota, o argumento que rechaça essa teoria serve, inclusive, de fonte orientadora para se ratificar o entendimento de que o MPE também não deve guardar qualquer vínculo com o Ministério Público da União. Se no âmbito da União e do seu Tribunal de Contas, existe um Ministério Público próprio e dito especial, e se este não é. definitivamente, o Ministério Público da União, então por qual motivo se dirá que existe um Ministério Público Especial apenas em relação à União, e não para aos Estados?

Segundo se observa, os adeptos desta teoria se baseiam no fato de que o art.128 não contemplou para os Estados, qualquer outra possibilidade de Ministério Público que não fosse o Ministério Público Estadual.

Data máxima vênia, essa afirmação não pode restar vencedora. Como se sabe, a Constituição Federal não é um amontoado de dispositivos estanques, incomunicáveis e que devam ser encarados apenas na medida de suas limitações gramaticais.

Se um artigo não exaure em si todas as suas possibilidades normativas, nada impede que um outro dispositivo. no choque da atividade hermenêutica, venha a suplementar, integrar, estender alguma manifestação não contida num determinado artigo de lei.

Comprovando de vez tal raciocínio, é preciso ressaltar:

\begin{tabular}{|c|c|}
\hline $\begin{array}{l}\text { Art.128 (CF) O Ministério Público } \\
\text { abrange: } \\
\text { I - O Ministério Público da União, } \\
\text { que compreende: } \\
\text { a) o Ministério Público Federal; } \\
\text { b) o Ministério Público do Trabalho: } \\
\text { c) o Ministério Público Militar; } \\
\text { d) o Ministério Público do Distrito } \\
\text { Federal a Territórios; } \\
\text { II - O Ministério Público dos } \\
\text { Estados. }\end{array}$ & $\begin{array}{l}\text { Art.73.. } \\
\$ 2^{\circ} \text {. Os Ministros do Tribunais de Contas da União } \\
\text { serão escolhidos: } \\
1 \text { - um terço pelo Presidente da República, com } \\
\text { aprovação do Senado Federal, sendo dois alternada- } \\
\text { mente dentre auditores dentre auditores e membros do } \\
\text { Ministério Páblico junto ao Tribunal, indicados em } \\
\text { lista tríplice pelo Tribunal, segundo os critérios de } \\
\text { antiguidade e merecimento; } \\
\text { Art.75. As normas estabelecidasnesta seção aplicam- } \\
\text { se, no que couber, à organizaçăo, composição e } \\
\text { fiscalização dos Tribunais de Contas dos Estados e } \\
\text { do Distrito Federal, bem como dos Tribunais e } \\
\text { Conselhos de Contas dos Municípios. } \\
\text { Parágrafo único. As Constituiçōes estaduais disporão } \\
\text { sobre os Tribunais de Contas respectivos, que serão } \\
\text { integrados por sete conselheiros. }\end{array}$ \\
\hline
\end{tabular}

Diante do cotejo desses dispositivos constitucionais, indaga-se: será mesmo que o Ministério Público dos Estados é o único apto a atuar na esfera estadual? Será que a Carta Maior não faz menção à existência ou a previsão de um Ministério Público 
junto aos Tribunais de Contas dos Estados? Será que a interpretação gramatical do artigo 128, inciso II, vai prevalecer sobre o princípio da unidade da Constituição?

Como se vê, a Constituição Federal prescreve um modelo para o Tribunal de Contas da União, e dentro desse modelo, prevê de forma clara e precisa, a atuação de um Ministério Público junto a essa Corte.

No art.75, ela contempla expressamente o princípio da simetria ao dispor que aos Estados serão aplicadas as mesmas normas da seção em que está o Tribunal de Contas da União, inclusive, no que se refere à organização e composição da referida corte, ou seja, prevê, com todas as letras, um Ministério Público junto aos Tribunais de Contas dos Estados, sem, contudo, desdizer o art.128, inciso II, da própria Constituição Federal.

Dessa forma, por mais que exista um dispositivo específico para regulamentar a existência do Ministério Público enquanto instituição, isso não quer dizer que ele se exaure em si mesmo, descartando as demais disposições constitucionais. Tanto a regra do art. $73, \S 2^{\circ}$, inciso $\mathrm{I}$, c/c com o art.75, como a do art. 130 da Constituição Federal, são normas de extensão do art.128, e, com ele, devem ser interpretadas.

Ademais, ressalte-se também, que embora o parágrafo único do art.75 preveja a atuação do poder constituinte decorrente, permitindo àos Estados disporem sobre o seu Tribunal de Contas, isso não dá a entender que possam essas Constituições Estaduais estabelecerem um modelo constitucional peculiar e estranho aos moldes apregoados pela Constituição Federal.

Sustentar a tese de que os Estados, no exercício do poder constituinte decorrente, poderiam legislar livremente a ponto de suprimir a previsão de um MPE - que é, diga-se, regra de repetição obrigatória para os Estados - é o mesmo que dizer que esse poder constituinte decorrente seria capaz de instaurar o sistema do contencioso administrativo, elidindo, destarte, os próprios Tribunais de Contas.

Se isto não se mostra possível, ou melhor, se não podem os Estados, no exercício do poder constituinte decorrente, suprimir os Tribunais de Contas, também não poderá, de igual teor e forma, eliminar o MPE, posto que ambos (Tribunais de Contas e Ministério Público), são normas de repetição obrigatória e tradutoras de um único modelo constitucional.

Vencida esta etapa, passa-se à análise de um MPE autônomo, posição adotada nesta obra, e que não encontra correspondência em nenhuma das teorias pretéritas.

\section{4) Natureza jurídica e assento constitucional do Ministério Público especial. posição adotada}

O cerne de toda a discussão envolvendo a natureza jurídica do Ministério Público junto ao Tribunal de Contas, como já se pôde perceber, está identificado em seu próprio amparo constitucional, advindo, portanto, da conjugação de quatro artigos a seguir enumerados:

Art.127 (CF). O Ministério Público é instituição permanente, essencial à função jurisdicional do Estado, incumbindo-lhe a defesa da ordem jurídica, do regime democrático e dos interesses sociais e individuais indisponiveis. 
Art. 128 (CF) O Ministério Público abrange:

I - O Ministério Público da União, que compreende:

a) o Ministério Público Federal;

b) o Ministério Público do Trabalho;

c) o Ministério Público Militar;

d) o Ministério Público do Distrito Federal e Territórios;

II - O Ministério Público dos Estados

Art.130 (CF) Aos membros do Ministério Público junto aos Tribunais de Contas aplicam-se as disposições desta Seção pertinentes a direitos, vedações e forma de investidura.

Art.73(...).

$\S 2^{\circ}$. Os Ministros do Tribunais de Contas da União serão escolhidos:

I - um terço pelo Presidente da República, com aprovação do Senado Federal, sendo dois alternadamente dentre auditores dentre auditores e membros do Ministério Público junto ao Tribunal, indicados em lista tríplice pelo Tribunal, segundo os critérios de antiguidade e merecimento;

Desta justaposição constitucional. exsurge como centro de controvérsias:

1) A omissão do art. 128 que não previu o Ministério Público junto ao Tribunal de Contas dentro do "quadro geral" do Ministério Público;

2) O deslocamento da previsão do MPE para os artigos 73 , § $2^{\circ}$, I, e 130;

3) A desastrosa opção do constituinte por esse formato, e, principalmente, a péssima redação deste último dispositivo constitucional.

Nessa abordagem crítica, o primeiro cuidado que se deve ter é investigar os rudimentos meritórios que antecederam a feitura do art. 130 da Constituição Federal.

$\mathrm{Na}$ verdade, antes de adentrar nesse propósito acima mencionado, é preciso registrar que embora os antecedentes históricos de todo e qualquer instituto jurídico contribuam de maneira insofismável para a sua melhor compreensão, tal enfoque deve ser alijado por ocasião desse estudo.

Decerto, não parece útil, nesse plano específico de discussão, que se retroceda à análise do "Parquet Especial Histórico", quando, no tempo presente, ainda não se sabe ao certo sua exata natureza institucional. Se sua delimitação e identidade são questionadas nos dias de hoje, não seria com referências históricas que essa dificuldade restaria atenuada, até porque, o "Parquet Especial Histórico" é, sem sombra de dúvidas, tão mais confuso do que o atual.

Nesse trilhar, a razão parece assistir a Paulo Salvador FRONTINI: "Inútil repisar, a propósito, velhas consideraçōes sobre suas origens legislativas. O esforço dos pesquisadores, investigando as conexões entre a Instituição e os procuradores do rei, embora respeitável, não oferece contribuição satisfatória para as dúvidas do momento. E, quiçá, ajude a aumentá-las". ${ }^{6}$ 
Efetuada tal ressalva, ao perquirir os dados doutrinários da restrita literatura acerca do tema, não subsiste nenhuma dúvida de que o aparecimento desse artigo 130 deveu-se muito mais a um resquício de ordem temporal, do que propriamente uma conviç̧ão da real natureza e necessidade do MPE como instituição autônoma.

De toda sorte, como já observado, parece que a intenção originária do legislador não foi realmente criar essa espécie de Ministério Público autônomo, mas sim, apenas garantir os direitos daqueles que já integravam o confuso quadro do antigo MPE, antes do advento da Constituição Federal de 1988.

No entanto, a partir do momento que o constituinte, seja lá por quais motivos, deixa de assegurar tais direitos num dispositivo qualquer do Ato das Disposições Constitucionais Transitórias - ADCT (que seria o foro adequado para a colocação desse tipo de direito intertemporal), e passa a contemplar o Ministério Público junto ao Tribunal de Contas em dois dispositivos no próprio texto originário da Constituição, garantindo, inclusive, os mesmos direitos, vedações e forma de investidura dos demais membros dos outros Ministérios Públicos, ele estabelece uma controvérsia de ordem conceitual a ponto de instituir uma situação embaraçosa de dificílima solução.

Apelando às manifestações coloquiais, desde o instante em que o legislador constituinte, "sem querer criar essa instituição ministerial autônoma", não contempla o MPE como parte integrante de um dos Ministérios Públicos - da União ou dos Estados - e vislumbra, paradoxalmente, dois artigos para aquele que foi esquecido dentro do "quadro geral" do Ministério Público, ele está institucionalizando, na própria Constituição Federal, uma verdadeira "sinuca" constitucional, uma zona de conflito, que só pode ser dirimida através de critérios de hermenêutica.

Dessa forma, não é negando a "sinuca", nem muito menos fingindo ela não existir, que se alcança soluções para dispositivos (aparentemente) incongruentes, ainda que estes mesmos dispositivos, sejam normas constitucionais contidas no texto originário da Constituição Federal.

É inegável que o legislador constituinte não foi feliz quando optou pelo tratamento dado na Constituição Federal ao Ministério Público junto ao Tribunal de Contas. Entretanto, essa é a dura realidade, e dela não se pode fugir.

De outra parte, assim como o desejo recôndito de um confuso legislador constituinte, revolto e inexperiente na cartilha democrática, tem-se a plena convicção de que realmente a melhor opção, o melhor modelo constitucional, seria fazer atuar junto aos Tribunais de Contas um representante do Ministério Público, seja dos Estados, seja da União (e aqui propriamente, o Ministério Público Federal), na medida de suas competências, como um autêntico defensor do patrimônio público e no mister dignificante de guardião da moralidade administrativa.

Todavia, embora essa fosse - talvez - a melhor opção para nosso modelo ministerial, o fato é que hoje existe, por causa do tão decantado art. 130 (sem esquecer o art.73) da Constituição Federal, um Parquet Especial composto em sua dimensão pragmática com toda uma gama de matizes próprias e específicas: previsão constitucional, atribuições, chefia (procurador geral), carreira de procuradores, estrutura 
organizacional, investidura através de concurso público exclusivo, autonomia legislativa, enfim, todo um aparato real e concreto que o distingue dos Ministérios Públicos da União e dos Estados, como uma verdadeira terceira via ministerial.

Por mais que o art. 128 da Carta Magna não preveja o Ministério Público junto ao Tribunal de Contas no rol daqueles que compõem o Ministério Público lato sensu, acredita-se que seja muito mais razoável, juridicamente, acatar a natureza autônoma do Parquet Especial, do que lhe tentar negar essa índole que lhe fora dada, ainda que de modo confuso e atabalhoado, pelo art. 130 da Constituição Federal.

Esclarecendo, sob o ponto de vista jurídico, é muito mais coerente fazer ajustes interpretativos em cima de uma opção mal-inspirada, tendo em vista uma ineludível realidade fática, do que continuar insistindo num caminho que essa mesma realidade já tratou de desmistificar.

Se, como dito, existe, e é fato, um MPE com todas as atribuições acima mencionadas, e do mesmo modo, esse MPE não integra, por disposição expressa da Constituição Federal, nem o Ministério Público da União nem dos Estados, não há, dessa forma, qualquer subsídio doutrinário que impeça o seu reconhecimento como órgão ministerial autônomo, a partir da experiência do arts. $73, \S 2^{\circ}$, I, e 130 da Constituição da República.

No afã de ilustrar o raciocínio anterior, é válido tomar como referência analógica o seguinte exemplo: suponha uma norma qualquer que identifique e reconheça, num certo dispositivo " $X$ ", quatro espécies diferentes de recursos, " $A$ ", " $B$ ", " $C$ " e "D".

Por conseguinte, dentro do mesmo liame de idéias, presuma um outro dispositivo "XX" da mesma norma, que preveja, posteriormente, uma outra espécie recursal denominada "E". Após sua promulgação e publicação, a doutrina especializada aponta como uma atecnia de redação legislativa a justaposição dessa quinta medida recursal em um dispositivo próprio, diferente e, portanto, desagregado das demais espécies recursais.

A lei é taxativa ao chamar essa quinta previsão "E", de recurso, embora disciplinada em preceito à parte. Diante dessa situação, indaga-se: será que o recurso "E" deixará de ser recurso por está disciplinado em dispositivo diverso daquele que instituiu o sistema recursal lato sensu? Será que o recurso "E" deixará de ser recurso porque foi disciplinado dentro de uma absoluta falta de propriedade técnica? Sofrerá ele a consequêencia impiedosa de ver-se desnaturado em sua concepção ontológica, por um simples equívoco de técnica legislativa? Terá a forma, adquirido, nesses enleados e obscuros dias, razões substanciais maiores do que o próprio conteúdo?

Mutatis mutandis, a mesma situação acontece com o Ministério Público junto ao Tribunal de Contas. A sua raiz ontológica (foi a própria Constituição Federal que o chamou de Ministério Público) independe de uma correta técnica legislativa ou da forma de distribuição em artigos de lei. Se um dispositivo qualquer não exaure em si a plenitude de suas possibilidades, não é a instituição não contemplada por ele que deve sofrer os ônus de tal esquecimento. 
Por falar em instituição, é preciso aqui abrir um enorme parêntese. Como é conhecido na doutrina, existe uma parcela de autores que tendem a considerar que o artigo 130 faz referência apenas à existência dos membros do Ministério Público junto ao Tribunal de Contas, e não, à instituição propriamente dita, que estaria, por conseguinte, fadada à extinção.

Não obstante o absurdo, que por si só, parece ser esta tese, não se pode deixar de refutá-la de forma veemente por ocasião deste estudo.

Múcio Vilar Ribeiro DANTAS, em artigo sobre o MPE preconiza: “O processo de elaboração constitucional não primou pela técnica e nem seria possível atingir a perfeição da forma no atropelo dos últimos dias em que a questão era concluir logo os trabalhos. Pode-se enumerar às dezenas os senões técnicos do Texto Maior, e não seria esse o único a justificar qualquer interpretação a partir de um seu aspecto puramente formal. A idéia é que vale, e a idéia está ali muito clara. Não fora isso, seria preciso passar um atestado de insanidade mental a todos os constituintes, por fazerem mencionar, na Constituição, membros de um Ministério Público que supostamente não existisse".?

Completando sua reação ao estapafúrdio que seria prever a existência só dos membros, mas não da instituição, o citado autor, na mesma obra, completa: "Na redação de uma Constituição, as questões implícitas ganham foros de consistência irretorquível. Falar de membros de um determinado Ministério Público é admitir implicitamente a existência desse Ministério Público. Que outro sentido, então, poderia ser emprestado ao artigo 130 da Constituição? Algo está ele querendo dizer e o que nunca estaria dizendo é que o Ministério Público junto aos Tribunais de Contas estaria extinto".

Como se vê, quando o art.130 faz alusão a "membros do Ministério Público junto ao Tribunal de Contas", ele está dizendo que por trás desses membros existe uma instituição chamada Ministério Público junto ao Tribunal de Contas (até porque, outra não poderia ser a conclusão), e que essa instituição, não pertence nem ao Ministério Público da União, nem ao Ministério Público dos Estados, posto que não fora contemplada no inciso I e II, do art.128. Com ser assim, se não integra nem um nem outro, mas, no entanto, ela existe como Ministério Público, a única alternativa lógica a ser considerada é no tocante ao reconhecimento de sua autonomia.

Investigando mais a fundo, se a Constituição não quisesse criar a "instituição Ministério Público junto ao Tribunal de Contas", garantindo apenas aos membros que lá já estavam o direito de continuar, teria apenas ressalvado tais direitos no ADCT, e não, mencionado, como mencionou no art.130, que será aplicado aos membros do MPE a mesma forma de investidura na carreira, como acontece para os demais membros de qualquer Ministério Público.

7 DANTAS, Múcio Vilar Ribeiro. O Ministério Público junto aos Tribunais de Contas. Ciência Jurídica, $n^{\circ}$ 43, jan/fev. 1992, p.322. 
Atribuir essa semelhança de investidura para os membros do MPE (o que não poderia ser diferente), é o mesmo que dizer que, doravante, todos os membros do Parquet Especial só serão nomeados após prévia aprovação em concurso público, conforme determina a Constituição em seu art.37, inciso II. Caso a Constituição quisesse extinguir o Ministério Público junto ao Tribunal de Contas, qual a lógica de dizer que, a partir de sua promulgação, a forma de investidura seria igual a dos demais membros do Ministério Público? Se ela estava extinguindo o MPE, por que admitir novas investiduras?

São por estas e tantas outras razões, que não se pode admitir teses desta natureza. Em sentido completamente oposto, ao invés de o Ministério Público Especial ter encontrado o seu crepúsculo, sua decadência, ele acha-se em plenas condições de buscar seu fortalecimento institucional, e o que é melhor, com autonomia e autoridade constitucional.

De tal maneira, voltando ao cerne da discussão após a referida ressalva, se a omissão do artigo 128 da Constituição Federal não desnatura a figura do MPE, e bem ou mal, não obstante a péssima opção e redação do art.130 do mesmo diploma, existe hodiernamente um Parquet Especial não vinculado a nenhum outro Ministério Público, a ilação final, repise-se, é a de que, pela conjugação desses dispositivos 128 e 130 - aliado a uma interpretação sistêmica do próprio texto constitucional, a melhor feição de se vislumbrar o MPE seria reconhecendo sua autonomia como instituição, como bem demonstra o silogismo ${ }^{8}$ abaixo:

PREMISSA MAIOR

PREMISSA MENOR

Art. 128 (CF) O Ministério Público abrange: I - O Ministério Público da Uniāo, que compreende:

a) o Ministério Público Federal;

b) o Ministério Público do Trabalho;

c) o Ministério Público Militar;

d) o Ministério Público do Distrito Federal e Territórios;

II - O Ministério Público dos Estados

8 "O método dedutivo, cuja forma é o silogismo, corresponde (...): chega ao conhecimento do particular baseando-se no conhecimento geral. Exemplo: todos os homens são sujeitos de direito; os negros são homens; logo: os negros são sujeitos de direito. Outro: todos os planetas apresentam forma redonda; a terra é um planeta; logo: a terra é redonda. A argumentação silogística, é pois, formada por duas premissas, das quais uma é genérica - premissa maior - a outra, particular premissa menor; às premissals segue-se uma conclusão ou ilaçāo, obtida mediante a aplicação da primeira premissa à segunda". DEL VECCHIO, Giorgio. Liçōes de Filosofía do Direito. $5^{a}$ edição. Coimbra, 1979, p. 321 . 
- Se o Ministério Público junto ao Tribunal de Contas é Ministério Público, porque a Constituição assim o denomina:

- Se existe, e é fato, como instituição dotada de todo um arcabouço operacional próprio;

- Se não há qualquer manifestação constitucional vinculando-o a algum dos Ministérios Públicos do art 128;

- Se há dois dispositivos constitucionais específicos (arts. $73, \S 2^{\circ}, I$, e 130), que embora confusos (principalmente o último), legitimam a existência de um Ministério Público junto ao Tribunal de Contas, reparando assim, a omissão de outro preceito (art.128);

\section{CONCLUSÃO}

- A conclusão é a de que se possa interpretar tais dispositivos da Constituição Federal como uma verdadeira extensão do artigo 128 , reconhecendo a autonomia do Ministério Público junto ao Tribunal de Contas - Ministério Público Especial - da seguinte maneira:

Art.128 (CF) O Ministério Público abrange:

I - O Ministério Público da União, que compreende:

a) o Ministério Público Federal;

b) o Ministério Público do Trabalho;

c) o Ministério Público Militar;

d) o Ministério Público do Distrito Federal e Territórios;

II - O Ministério Público dos Estados

III - O Ministério Público Especial, com atribuições perante os Tribunais de Contas da União e dos Estados.

Como dito, embora essa possa não parecer a melhor opção para modelo constitucional, haja vista que tudo restaria muito mais simplificado se não existisse um MPE, e todas as suas atribuições fossem conduzidas pelos membros do Ministério Público da União (Ministério Público Federal) e dos Estados, cada qual em suas esferas de atribuições, a questão é que pela forma como foi encartado este artigo 130 (não esquecendo o art.73, $\S 2^{\circ}$, I) e pelos efeitos jurídicos que dele resultam, outra não poderia ser a solução, senão considerar a interpretação acima proposta, ou, pelo menos, algo em torno dela.

O que não se concebe, é considerar o MPE como integrante do Ministério Público da União ou dos Estados, quando a própria Constituição Federal não quis 
assegurar essa condição, e quando a efetiva existência ontológica desse Parquet não permite tal relação de dependência, face aos inúmeros aspectos fáticos da realidade. ${ }^{9}$

Ressaltar que o MPE, diante de todas as constatações acima verificadas, seria uma simples espécie de órgão especializado dentro da carreira do Ministério Público da União ou dos Estados, não mais convence.

Este argumento serve muito mais como uma tentativa de camuflar os efeitos da opção do legislador do que propriamente tentar resolver as implicações jurídicas que desta opção resultam, pois, como se vê, o Parquet Especial simplesmente não é um mero desdobramento, tanto na essência, como na prática, dos outros Ministérios Públicos.

Quando a Constituição Federal quis criar setores de especialidades para o Ministério Público, ela consignou expressamente o Ministério Público Militar e o Ministério Público do Trabalho dentro do Ministério Público da União (art.128). Se ela não agiu do mesmo modo para o MPE é porque, de uma vez por todas, não quis equipará-lo à mesma situação do Ministério Público Militar e do Trabalho.

Como se vê, fica extremamente difícil vislumbrar uma saída para a colocação constitucional do Ministério Público junto ao Tribunal de Contas, que seja diversa da que vem sendo defendida ao longo desta exposição.

Num momento, ainda de forma provisória, a Assembléia Constituinte prevê o Parquet Especial como integrante do Ministério Público da União (art.128, inciso I, alínea "e"); já no texto constitucional definitivo, o exclui dessa posição, e não mais o prevê em qualquer inciso ou alínea do art.128, vindo a colocá-lo em outros dispositivos, como o fez, no art.130 e no inciso I, do $\S 2^{\circ}$, do art. 73 .

O que é certo, é que dentre tantas irresoluções e vacilos, criou-se um problema estrutural de considerável complexidade jurídica.

Pois bem, é a partir dessa série de hesitações do constituinte brasileiro que a doutrina tem que enfrentar - diretamente - o problema da justaposição do Ministério Público junto ao Tribunal de Contas, sob pena de torná-lo letra morta no próprio corpo constitucional.

Sabendo todos, que nem a lei, nem a Constituição Federal, pelo menos "juridicamente", contém locuções inúteis ou palavras mortas, é que se pode dizer que a solução defendida nesta obra busca "salvar", diante das circunstâncias, a péssima técnica legislativa dada (principalmente) ao art.130 da Constituição Federal, enquanto não vem uma proposta de emenda constitucional (PEC) para delimitar, com mais precisão, os contornos jurídicos do MPE.

Entrementes, como as mudanças legislativas não estão ao alcance da doutrina - com exceção do papel inspirador de reformas - o máximo que ela pode fazer é perquirir, em trabalhos de interpretação como este, a viabilidade de dispositivos polêmicos, na exata medida de seu alcance e extensão.

9 Possui chefia própria - Procurador Geral, carreira específica para procuradores, estrutura organizacional destacada, forma de provimento através de concurso exclusivo para a carreira, e. portanto, distinto dos demais membros do Ministério Público etc. 


\section{5) Diretrizes constitucionais para uma nova interpretaçāo do artigo l30 da}

constituição federal

É curial em todas as manifestações de ordem doutrinária, a assertiva de que o ordenamento jurídico, como unidade que é, resolve e extingue, ele próprio, os problemas de interpretação e de aparente incongruência entre seus dispositivos. Esta é uma regra geral, e salvo melhor juízo, unânime em todas as fontes jurídicas.

De outra parte, para que essa asseveração possa se revestir de unanimidade, o ordenamento jurídico autoriza o seu intérprete a buscar nas fontes principiológicas o conhecimento e as revelações que lhe permitem desembaraçar-se das incoerências legislativas, não deixando, desse modo, nenhuma indagação sem resposta.

Isto quer dizer que por mais clara que seja a norma, ela precisará sempre de interpretação, interpretação esta, que deverá ser sistêmica, coordenada com os demais dispositivos por via de um processo lógico-sistemático como bem assevera Vicente RÁO: "Melhor se apura o pensamento contido em uma sentença quando se a enquadra na ordem sistemática do conjunto de disposições de que faz parte, ou quando se confronta com disposições outras, mas ligadas, todas, entre si, por identidade ou afinidade de princípios". ${ }^{10}$

Ora, se até as disposições mais clarividentes precisam ser interpretadas, o que não dizer daquelas mal redigidas ou que ensejam dúvidas e contradições? Para estas, mais do que nunca, é que se torna indissociável a conjugação da carga principiológica com a adoção do processo lógico-sistemático.

Assim, concretizada essa perspectiva, dispositivos constitucionais ou artigos de lei que aparentam resultar variações em seu comando normativo, ou seja, que demonstram conter em seu conteúdo várias possibilidades interpretativas, devem tornar-se objeto preferencial da doutrina no exame de princípios e técnicas de hermenêutica.

Dentre estes, o art.130 da Constituição Federal é, sem sombra de dúvidas, um dos que mais merecem atenção. A sua colocação constitucional não foi das mais sensatas, sua redação não é um primor de técnica legislativa, as discussões em torno de sua existência parecem não ter sido exaurientes e conclusivas sobre o que se queria (naquele momento histórico) criar, de maneira que, a dedução que se tira é a de que existe uma névoa em torno de tal artigo, dificultando a melhor observação do exegeta, o que possibilita, consequentemente, existir tanta dubiedade em torno da natureza jurídica do Parquet Especial.

Toda essa situação de ambigüidades e hesitações em torno do famigerado art.130 parece se adequar perfeitamente ao traçado sempre brilhante de J.J Gomes CANOTILHO, quando o mesmo se refere à chamada "não correspondência biunivoca entre disposiçōes e normas": "É muito corrente, em algumas sentenças do Tribunal Constitucional, a alusão a "fragmentos de normas", a "segmentos de normas", a "articulação de normas". Convém tomar contacto com estes conceitos que, de resto, são também usuais em obras de doutrina sobre "metodologia jurídica", "linguagem jurídica" e "raciocínio jurídico". Além de serem conceitos correntes nos discursos

10 RÁO, Vicente. O Direito e a Vida dos Direitos. $3^{3}$ edição. Vol. 1. São Paulo: Revista dos Tribunais, 1991, p. 442. 
jurisprudenciais e doutrinários, eles constituem importantes instrumentos metódicos no trabalho de interpretação/concretização do texto constitucional"."

Por conseguinte, logo após tais prolegômenos, o mestre português encarta o que chama de disjunção de normas como o primeiro ponto dessa narrativa: "Uma só disposição (formulação, enunciado) pode exprimir uma ou outra norma, segundo as diversas possibilidades de interpretação. Tomemos, como exemplo, o art. 24\% 1 da CRP: "A vida humana é inviolável". Esta disposição pode conter, pelo menos, três normas, consoante o significado que lhe é adscrito: Norma l: "a vida humana é inviolável desde o momento do nascimento até ao momento da morte": Norma 2: "a vida humana é inviolável desde o momento da concepção até o momento da morte"; Norma 3: "a vida humana é inviolável desde o momento em que, de acordo com os dados da ciência, começa a haver vida intra-ulterina até o momento da morte". ${ }^{12}$

E por fim, concluindo seu raciocínio, registra: "Como se vê, não é indiferente, para efeitos de protecção da vida e da punição da interrupção da gravidez, optar-se por uma ou outra interpretação. Podemos representar simbolicamente esta disjunção $\mathrm{D} \rightarrow \mathrm{N} 1$ ? N2? N3?". ${ }^{13}$

Trazendo a experiência da disjunção de normas ao caso ora examinado, fica evidente que o artigo 130 da Constituição Federal, salvadas as devidas proporções, se reveste das mesmas características do art. $24^{\circ} / 1$ da CRP, posto que, a princípio, admite várias facetas interpretativas em torno de seu real alcance e significado. Esta assertiva fica ainda melhor traduzida, quando se expõe, a partir da fórmula disjuntiva citada por Canotilho (D N1? N2? N3?) o seguinte esboço demonstrativo:

Art.127 (CF). O Ministério Público é instituição permanente, essencial à função jurisdicional do Estado, incumbindo-lhe a defesa da ordem jurídica, do regime democrático e dos interesses sociais e individuais indisponíveis.

Art.128 (CF) O Ministério Público abrange:

I - O Ministério Público da União, que compreende:

a) o Ministério Público Federal;

b) o Ministério Público do Trabalho;

c) o Ministério Público Militar;

d) o Ministério Público do Distrito Federal e Territórios;

II - O Ministério Público dos Estados

Art.130 (CF) Aos membros do Ministério Público junto aos Tribunais de Contas aplicam-se as disposições desta Seção pertinentes a direitos, vedações c forma de investidura.

\begin{tabular}{|c|c|c|c|}
\hline \multicolumn{2}{c}{$\downarrow$} & \multicolumn{2}{c|}{$\downarrow$} \\
\hline Norma 01: & Norma 02: & Nomma 03: & Norma 04: \\
MPE vinculado ao & MPE incorporado & MPE como parte da & MPE autônomo, como \\
Ministério Público & ao Ministério & estrutura interna dos & uma verdadeira terceira \\
da União & Público dos Estados & Tribunais de Contas & via ministerial \\
\hline
\end{tabular}

I CANOTILHO, J.J. Gomes. Direito Constitucional e Teoria da Constituição. $3^{2}$ ediçũo. Coimbra: Almedina, 1999, p. 1.129.

12 CANOTILHO, J.J. Gomes. Op. cit. p. 1.130.

13 CANOTILHO, J.J. Gomes. Op. cit. p. 1.130. 
Como se está a ver, apesar de ser o art. 130 o objeto principal da presente análise, ele não pode ser considerado isoladamente como uma espécie de norma segregada, à parte, portanto, dos demais dispositivos que tratam do Ministério Público.

Enquanto estiver solitário na observação analítica, dificilmente encontrará saída para a variação de caminhos que, dele (art. 130), podem surgir. Como esta alternativa não é contemplada pelo ordenamento jurídico, isto é, como este não permite que um dispositivo (principalmente sendo norma originária da Constituição) fique sem uma resposta à altura de seus questionamentos, a solução parece mesmo estar na avaliação dos já referidos processos lógico-sistemáticos combinados com os princípios de interpretação constitucional.

A disjunção só causa perplexidade e dúvida porque incide sobre um dado preceito destacado. Na medida que se aproxima esse mesmo preceito a outros de igual índole, e se passa a adotar os processos e princípios mencionados, pode-se, finalmente, chegar a melhor solução, que antes parecia não existir.

Já que os princípios são atalhos imprescindíveis dentro dessa peregrinação, é de extrema importância evocar o estudo do "Catálogo Tópico dos Princípios da Interpretação Constitucional", a que se referiu CANOTILHO a partir da experiência de outros autores (HESSE, LARENZ, PAWLOWSKI): princípio da unidade da constituição, o princípio do efeito integrador, o princípio da máxima efectividade, o princípio da justeza ou da conformidade funcional, e por fim, o princípio da concordância prática ou da harmonização.

No impulso da mesma égide analítica, de nada adiantaria a conclamação desses princípios, se não fossem eles de extrema utilidade para a fundamentação teórica da posição que aqui vem sendo defendida - autonomia do MPE como terceira via ministerial.

Ressalte-se, porém, que agora não se irá mais elidir as correntes que vêem no MPE uma qualificação diversa da que vem sendo adotada nesta obra. Esta exposição já foi consolidada, não sendo mais necessário retomá-la.

Por isso, passa-se, neste momento, a confrontar o enunciado de cada princípio de interpretação constitucional com a exata dimensão ontológica dada aqui ao MPE, para que, com isso, se tenha a ampla conviç̧ão de sua plena viabilidade como manifestação doutrinária.

Seguindo esta orientação geral, a Constituição da República deve, pois, ser estudada e interpretada em seus aspectos globais, em toda sua estrutura normativa, para que possa, assim, amenizar os espaços de tensão a que alude Canotilho. Essa idéia basilar e perfunctória é justamente o que sedimenta o princípio da unidade da constituição como causa primária em qualquer exercício de interpretação.

De acrescer, os aspectos pragmáticos deste princípio se parecem em muito com o que foi mencionado anteriormente em relação ao exemplo dos recursos. Se uma lei prevê, num artigo $X$, quatros espécies recursais, $A, B, C$ e $D$, o recurso " $E$ ", que vier a ser disciplinado em outro dispositivo da mesma norma, não deixará de ser recurso apenas por não estar previsto na disposição tida como "geral". A simples colocação posterior em nada altera sua natureza, desde que, é claro, seja ele, objetivamente, recurso. 
Dessarte, não é porque o Ministério Público que atua junto ao Tribunal de Contas não foi contemplado no art.128, que ele deixará de ser Ministério Público na acepção mais restrita da palavra. Confrontando os arts 127-128-130, como uma verdadeira unidade lógico-sistemática, vê-se que a interpretação mais coerente com o princípio da unidade é conceber este último (art.130), como uma norma de extensão do art.128, integrando-o, desta maneira, às demais carreiras ministeriais.

Outrossim, corolário direto do princípio da unidade é o princípio do efeito integrador. Integrar para fortalecer, essa é a advertência maior do princípio. Quando o MPE deixar de ter a esdrúxula condição de "Ministério Público doméstico" e passar a ser reconhecido como Ministério Público que é, senhor de suas iniciativas e responsabilidades, só estará contribuindo para o fortalecimento da "Instituição Ministério Público", e não, enfraquecendo-a, como querem alguns.

Com um MPE reconhecidamente autônomo, ganha o Ministério Público, e acima de tudo, ganha a sociedade, que terá um órgão mais atuante e menos burocrático.

$\mathrm{Na}$ força desses argumentos, sabe-se que "a uma norma constitucional deve ser atribuído o sentido que maior eficácia lhe dê". ${ }^{14}$ Trata tal expressão do princípio da máxima efetividade, e embora este entendimento esteja primordialmente relacionado com as normas programáticas e com os direitos fundamentais, nada impede que seja utilizado, também, como diretriz interpretativa para o art.130 e, por conseguinte, para o MPE.

Isto porque é exatamente de efetividade que o Parquet Especial precisa. Num tempo em que as atitudes contra o patrimônio público se multiplicam, ele necessita converter todo o seu potencial, oriundo de uma privilegiada posição, em ações concretas, diretas, seja em que instância for e até onde merecer sua atuação institucional.

No entanto, a pergunta que fica é: será que o Parquet Especial, como mero órgão da estrutura interna do Tribunal de Contas, estaria adquirindo a máxima efetividade que dele se espera? Conhecendo sua posição privilegiada no exame dos atos, contratos e procedimentos administrativos, e mais, sabendo do que seria capaz de realizar se fosse encarado não apenas como um órgão burocrático e fiscalizador, mas sim, como um órgão transformador de seu tempo, não estaria na hora de creditar uma nova cara, um novo formato, uma nova visão para o MPE?

Decerto, a partir do momento que o Ministério Público junto ao Tribunal de Contas for reconhecido como deve, estará ele, atingindo a "máxima efetividade", razão por que, tal princípio, se apresenta em total consonância com as diretrizes aqui delineadas.

Já o princípio da justeza ou conformidade funcional, se não tem, assim como os outros, o condão de ajudar nessa linha argumentativa, também não atrapalha. Na lição de Canotilho, este enunciado principiológico visa apenas que não se deve permitir, em sede constitucional, a alteração de repartição de funções, outrora estabelecidas pela Constituição. 
Diz ainda o dito autor, que nenhuma interpretação pode sair vencedora quando afetar, subverter ou perturbar o esquema de organização funcional estabelecido na Constituição. Na medida deste magistério, não é demais reafirmar, que em nenhum momento a posição aqui assumida vai de encontro ao preconizado neste princípio. Se a competência do MPE, em substância, é a mesma do Tribunal de Contas, e se ela está devidamente prevista no texto constitucional, não é com o reconhecimento de sua verdadeira natureza que o MPE irá subverter a ordem constitucional.

Conforme foi demonstrado na análise do princípio da unidade, é justamente com este reconhecimento que se estará dando conformidade funcional ao Ministério Público junto ao Tribunal de Contas. Se ele já tem sua competência delimitada, precisa apenas de autonomia para exercer tal competência, desvinculando-se, assim, da conveniência ou da vontade de algum outro órgão. Ao contrário de perturbar a ordem constitucional, essa idéia só conforta e ratifica a competência do Parquet Especial, posicionando-o como verdadeiro Ministério Público.

Por outro lado, o princípio da concordância prática ou da harmonização, que apesar de encontrar campo próprio de atuação nos chamados direitos fundamentais, também pode ser adaptado, para aqui, prestar sua colaboração ao MPE.

Com esse intuito, levando-se em conta o que é Ministério Público, o MPE, do modo como vem sendo entendido pelas inúmeras teorias que o estuda, parece não estar perfeitamente adequado, harmonizado, com a própria instituição que integra, pois muitas vezes, ele parece que é, mas não é, e que pode, mas não pode, instaurando aí uma dessimetria de ordem constitucional. Esta situação incômoda e distorcida dá a entender que o Ministério Público junto ao Tribunal de Contas é Ministério Público (porque a Constituição assim o chama), mas ao mesmo tempo não é (primeiro, porque não integra o rol do art.128; e segundo, porque tem sua natureza vinculada a um tribunal - que outro Ministério Público tem essa condição?).

De outra parte, não obstante essa evidência inafastável, ele ainda tem que se contentar com inúmeras restrições em sua atuação como verdadeiro Ministério Público, só pelo fato de encontrar, nos Tribunais de Contas, seu campo imediato de incidência e atuação funcional.

Ora, o Ministério Público junto ao Tribunal de Contas é considerado Ministério Público Especial só porque atua, originariamente, junto aos Tribunais de Contas (e não, perante juízes ou tribunais jurisdicionais). Seu traço característico, sua marca diferenciadora, é tão-somente esta, pois, no mais, ele é Ministério Público como qualquer outro.

Diga-se ainda, que ele só tem esta "especialidade" de atuar junto às respectivas Cortes de Contas, porque a sociedade precisa - naquele momento estratégico em que os fatos ainda estão no âmbito administrativo - de um órgão técnico especializado, isento, fiscalizador, independente, enfim, de um órgão que seja senhor de suas decisões quando for apontar o certo e o errado na Administração Pública. Por mais que as Procuradorias (dos Estados, dos Municípios, das Autarquias etc.) possam garantir a lisura dos procedimentos administrativo através de pareceres fundamentados, elas não têm, nem mesmo poderiam, a mesma função destinada ao Ministério Público, daí sua vital necessidade. 
No tópico anterior, procurou-se mostrar as principais vertentes teóricas sobre o Parquet Especial, bem como, as incompatibilidades que dessas vertentes resultam, até porque, todas essas incongruências, são a máxima expressão de que o princípio da concordância prática ou da harmonização não vem sendo observado em relação ao Ministério Público junto ao Tribunal de Contas.

De todas as alternativas mencionadas no quadro de disjunção de normas, isto é, de todas as opções interpretativas que do art. 130 podem surgir, a que mais se adequa ao princípio da harmonização, é a que vem sendo sustentada neste trabalho.

Pelo caminho que se traçà, o Ministério Público junto ao Tribunal de Contas harmoniza-se mais com a "Instituição Ministério Público", o artigo 130 se robustece em importância e utilidade. e, em combinação com o art.73, $\S 2^{\circ}$. inciso I, da Constituição Federal, adquire força suficiente para instituir um MPE autônomo e livre de qualquer vínculo que o diminua em sua verdadeira condição.

Neste conspecto, retome-se, mais uma vez, a análise do art. 130 em interpretação sistemática com o art.73, $\S 2^{\circ}$, inciso I, da Constituição Federal:

Art.73.

$\$ 2^{\circ}$. Os Ministros do Tribunais de Contas da União serão escolhidos:

1 - um terço pelo Presidente da República, com aprovação do Senado Federal, sendo dois alternadaniente dentre auditores e membros do Ministério Público junto ao Tribunal. indicados em lista tríplice pelo Tribunal. segundo os critérios de antiguidade e merecimento:

Art.130 (CF) Aos membros do Ministério Público junto aos Tribunais de Contas aplicam-se as disposições desta Seção pertinentes a direitos, vedações e forma de investidura.

Deste novo recurso comparativo, pode-se tirar a seguinte conclusão: se a essência e o foco do art 130 estiver apenas no que tange à extensão de direitos, vedações e forma de investidura aos membros do MPE, o artigo é totalmente inútil, pois se o Ministério Público junto ao Tribunal de Contas é Ministério Público, e todas essas previsões já estão inscritas na seção I, do Capítulo IV, Das Funções essenciais à Justiça (cf. art. 127 e 128 da Constituição Federal), não haveria qualquer razão, nem sentido, para essa repetição. Já que a norma não contém palavras inúteis (principalmente sendo ela norma originária da Constituição) o cerne da questão, ou melhor, o ponto nuclear do artigo, transmuda-se de uma simples redundância, para a inconteste previsão constitucional de que existe, fora do art. 128 , uma outra via ministerial: o Ministério Público junto ao Tribunal de Contas.

Reitere-se ainda, o que foi mencionado em linhas pretéritas por Múcio Vilar Ribeiro Dantas, quando afirma que o arts 130 e $73, \S 2^{\circ}$, I, da Constituição Federal, criaram uma verdadeira instituição, qual seja, o Parquet Especial. Caso contrário, 
como se poderia prever a existência de membros se não existisse instituição? Como se poderia, por exemplo, prever a existência de Promotores de Justiça, se não existisse a "Instituição Ministério Público Estadual"?

De qualquer forma, é a previsão constitucional desse parquet, e não os direitos, vedações e forma de investidura, que "salva" o artigo e que permite concluir por sua natureza autônoma, como terceira via ministerial.

Mas, se é assim, que razão então teria o art. 130 para repetir direitos já contemplados nos arts. 127 e 128 da Constituição? Conquanto se diga que esta não foi a intenção do legislador, a resposta parece estar, pela harmonização dos preceitos normativos diante das circunstâncias, na função de assegurar, expressamente (como uma espécie de plus, uma segurança a mais), o reconhecimento da natureza do Ministério Público junto ao Tribunal de Contas como verdadeiro Ministério Público, ainda que ele atue, originariamente, junto a um tribunal não jurisdicional.

Rejeitada essa alternativa, qual o sentido então de a Constituição atribuir aos membros do Ministério Público junto ao Tribunal de Contas, os mesmos direitos dos demais Ministérios Públicos, se não for para reconhecer sua própria natureza de Ministério Público? A vitaliciedade, por exemplo, é uma prerrogativa dos membros do Poder Judiciário e do Ministério Público, se o MPE não fosse "literalmente" Ministério Público, qual a razão de se atribuir, aos seus membros, a prerrogativa da vitaliciedade?

Com este propósito, o art.130, vislumbrado na sua real dimensão aqui exposta, e em interpretação sistemática com o arts. 128 e $73, \S 2^{\circ}$, inciso I, pode finalmente livrar-se do fantasma da inutilidade, porque com esta interpretação, terá ele adquirido uma outra perspectiva no seu enquadramento constitucional.

Contudo, não se pode deixar de assinalar, que esta posição acima descrita não significa que se está criando um novo Ministério Público. O Ministério Público junto ao Tribunal de Contas não é nenhuma novidade, haja vista que sempre esteve presente no texto constitucional desde a promulgação da Carta Maior em 1988. O esforço que aqui se depreende não se justifica para criar absolutamente nada, mas sim, para reconhecer um dado concreto e material que já existe, para se compreender, que o art. 128 não é taxativo na previsão das carreiras ministeriais, pois o art. 130 combinado com o art. $73, \S 2^{\circ}$, inciso I, prevêem uma outra via ministerial, como se existisse, na prática, um verdadeiro inciso III no art. 128 da Constituição Federal.

O grande papa João XXIII, por ocasião do concílio Vaticano II, dizia: "o evangelho não mudou, nós é que passamos a compreendê-lo melhor". Apesar da enorme distância temática, pode-se assegurar a mesma idéia, tendo em vista que não se criou um novo MPE, nem muito nenos ele mudou, apenas, agora, pode-se compreendê-lo melhor.

Por fim, não se pode deixar de reservar um espaço de análise para rechaçar a posição daqueles que sustentam que da mesma forma que o legislador não quis integrar o Ministério Público junto ao Tribunal de Contas ao Ministério Público da União (tanto que o retirou do art.128, inciso I, alínea "e"), também não o queria como órgão autônomo. 
Esta oração é de suma importância, haja vista que aqui se pára para investigar a vontade do legislador. A par desta assertiva, quem mostra o caminho para tal resolução é o mestre Vicente Ráo, no clássico O Direito e a Vida dos Direitos, quando trata do processo lógico-jurídico ou científico.

Discorrendo sobre este último, o citado autor refere-se a três elementos fundamentais: a ratio legis, a vis e a ocasio legis. Destas, a que parece mais relevante à presente discussão é a vis, ou, segundo RÁO, " a virtude normativa do preceito, que lhe advém, não da vontade subjetiva de quem o elaborou, mas da eficácia intrínseca e objetiva adquirida ao se destacar de seu autor."

Decerto, ninguém melhor do que o próprio RÁO para explicar tal proposição: "A soma dos resultados dessas três investigações devia tender, segundo antiga doutrina hoje abandonada, a demonstrar a vontade do legislador, considerada subjetivamente, como sendo o pensamento do autor, ou elaborador, da norma jurídica. Admite-se hoje, ao contrário, que essas investigações devem conduzir o intérprete na busca, não do querer subjetivo do autor do preceito, mas da vontade e do pensamento que animam a própria norma, havida como expressão atual da vontade coletiva". ${ }^{15}$

Traduzindo para uma linguagem coloquial, se um artesão tem a intenção de construir um violino, mas faz um violão, o que importa para o mundo real é que ali se terá um violão. Independentemente de como se queira chamar esse violão, ele será o que é (violão), ainda que se chame - de forma equivocada - de violino.

Sendo assim, esse violão sempre será "violão", pois esta é a sua natureza. Se seu formato, sua estrutura, sua dimensão é de violão, e não obstante, o som que dele se faz sentir também $\dot{e}$ de violão, não tem mais nenhum sentido investigar qual foi a vontade do artesão, pois, objetivamente, o que ele criou não foi um violino.

A mesma situação se aplica ao MPE. Muito embora a vontade do legislador não tenha sido a de criar um "violão", mas sim um "violino", ou seja, apesar do seu desiderato ter sido o de não vislumbrar um Ministério Público junto ao Tribunal de Contas forte, atuante, diligente e, principalmente, autônomo, a partir do momento que se observa com mais acuidade o arts. $73 \S 2^{\circ}, \mathrm{I}$, e 130 , e, por conseguinte, sua conjugação com o arts. 127 e 128, vê-se que seu desejo íntimo pouco irá importar, pois ele, assim como o artesão, não pode tirar do violino o som de um violão.

Estas são, portanto, as diretrizes que devem ser consideradas nessa proposta de interpretação do Ministério Público que atua junto ao Tribunal de Contas. Numa análise mais consistente, se observa que a posição adotada neste ensaio está em plena conformidade com todas esses processos lógicos e princípios interpretativos, e que estes são, na verdade, a própria fundamentação teórica para a interpretação adotada.

Por mais que o art.130 e o Ministério Público Especial continuem sendo fonte de sucessivos questionamentos (e enquanto não se consolida um interesse político para justificar uma proposta de emenda constitucional, que pudesse, quem sabe, dirimir tantas dúvidas). pelo menos no exercício da interpretação doutrinária, o Parquet Especial é plenamente viável como instituição autônoma. 
A esse respeito, finaliza-se com Vicente RÁO, que sobre a interpretação doutrinária, deixou o seguinte legado: "Sua maior valia não resulta da autoridade de quem a pratica, por muito que o conceito e o prestígio de um jurista possam pesar e valer; resulta, sim, de seu caráter científico e especulativo, da força da convicção do raciocínio que envolve". E valendo-se da lição de PLANIOL em seu Traité Elém de Droit Civil, consigna: "é a mais livre de todas as interpretações, porque é puramente teórica; a mais fecunda, porque se desenvolve sem peias; a que confere às suas conclusões a amplitude, a lógica e o poder de uma síntese, porque não se fecha no exame de uma questão isolada". ${ }^{16}$

\section{6) Ministério Público especial autônomo. Novas perspectivas}

Através das proposições e diretrizes mencionadas, procurou-se estabelecer a exata dimensão do problema do ser do Ministério Público junto ao Tribunal de Contas. Nesta nova linha de análise, é preciso que a atenção incida sobre os limites do que pode fazer, sendo, ele, verdadeiramente, Ministério Público.

Desta simples constatação, vê-se que a assertiva, ou melhor, o pseudo princípio de que o MPE atua apenas como custos legis, não tem razão para continuar existindo, primeiro, porque embora sua função primordial seja fiscalizatória, ele também atua como dominus littis, quando, por exemplo, promove uma representação ao próprio Tribunal de Contas; e segundo, porque sendo Ministério Público, não pode ter os limites de sua capacidade funcional reduzida, só porque atua (diretamente) perante às Cortes de Contas.

Negar a um Ministério Público - seja ele qual for - acesso ao Poder Judiciário na condição de autor, além de um insuperável paradoxo, é negar a sua própria natureza de Ministério Público. Como já foi dito, o fato de o MPE possuir assento funcional junto aos Tribunais de Contas (condição esta que o torna especial), não significa dizer que ele estará circunscrito apenas a essa Corte, como se existisse, para si, uma exceção ao princípio da inafastabilidade do Poder Judiciário.

Entretanto, para assegurar o teor desta asseveração, o Ministério Público Especial tem que ter em mente duas perspectivas: 1) buscar a declaração e o reconhecimento de sua legitimidade nas vias judiciais, justamente quando os Tribunais de Contas não mais estiverem garantindo a defesa da ordem jurídica; e 2) procurar estender essa mesma legitimidade, para poder habilitar-se concorrentemente no patrocínio de ações judiciais (v.g. ações civis públicas), quando vislumbrar, nos processos em que atua, a real necessidade de tais proposições.

Quanto à primeira perspectiva, o ponto inicial a ser vislumbrado é o princípio da inafastabilidade do Poder Judiciário, previsto no art. $5^{\circ}$, inciso XXXV, da Constituição Federal: "a lei não excluirá da apreciação do Poder Judiciário lesão ou ameaça a direito".

16 RÁO, Vicente. Op cit. p. 429. 
Assim, independente da natureza, da hierarquia ou da esfera de poder, qualquer lei ou ato normativo que vá de encontro a este enunciado - que é direito fundamental, e, portanto, cláusula pétrea da Constituição - será flagrantemente inconstitucional.

Não obstante essa constatação elementar, a partir de sua essência ministerial, o MPE não pode se deixar subjugar com características que o Ministério Público, como instituição, não possui. Chamá-lo de "especial" não significa desnaturá-lo como Ministério Público, e se todo Parquet tem dupla função - custo legis e dominus littis - ao MPE também deverá ser assegurado idêntico direito.

Ora, agir, do mesmo modo que é dever funcional do Ministério Público, também é direito de seus integrantes. Se existe o direito de ação, e este, é exercido pelo Ministério Público, logo, sabendo que o Ministério Público junto ao Tribunal de Contas é Ministério Público, não se pode deixar de reconhecer esse mesmo direito aos membros do Parquet Especial.

Não se está dizendo com isso, que deva o MPE instaurar uma panacéia jurídica recorrendo sempre ao Poder Judiciário, quando deveria, na verdade, ele mesmo preservar a competência do Tribunal de Contas. Sua atuação é perante o Tribunal de Contas, e assim deve agir, seja interpondo recursos, seja promovendo representações.

No entanto, ocasiões há em que as medidas tomadas perante as Cortes de Contas não mais são garantidoras da ordem legal e da moralidade administrativa, sendo, portanto, imprescindível, o socorro às vias jurisdicionais. Essa garantia de jurisdição é importantíssima para o MPE, principalmente como artefato do poder jurídico para delimitar a atuação constante do poder político.

E nisso, é preciso que se reconheça que os Tribunais de Contas muitas vezes trabalham numa linha bastante tênue entre o poder jurídico e o poder político. Não que este último poder se sobreponha àquele. mas é inegável que, neste âmbito de atuação, a armadura do poder jurídico precisa ser mais forte e conter mais garantias, e nestas garantias, não pode faltar o acesso ao Judiciário, sempre que as circunstâncias assim o exigir.

Levando-se em consideração: a) que o MPE só é especial porque atua imediatamente (e não exclusivamente) perante um tribunal não jurisdicional; b) que como visto, é Ministério Público, e como tal, detém as mesmas condições dos demais Ministérios Públicos; c) que está garantido pelo principio da inafastabilidade do Poder Judiciário (art. $5^{\circ}$, inciso XXXV, da Constituição Federal); d) que é sua função institucional defender a ordem jurídica em sua concepção mais ampla; e) que pela sua posição estratégica está, melhor do que ninguém, posicionado para constatar a malversação de verbas; indaga-se: qual seria o motivo de não se reconhecer a legitimidade do MPE, numa dada relação jurídica frente ao Poder Judiciário?

Como se sabe, o Ministério Público do Trabalho, por exemplo, não transfere para o Ministério Público Federal, a iniciativa na proposição de ações civis públicas nos casos em que lhes são afetos. Sendo assim, por qual razão teria, verbi gratia, o Ministério Público que atua junto ao Tribunal de Contas da União, representar, transferir uma responsabilidade que também é sua, para o Ministério Público Federal? Se ele fiscaliza, requisita, investiga, descobre desvio de verbas, (muitas vezes 
de verbas estratosféricas, que dizem respeito a toda sociedade), por qual motivo deve transferir para o Ministério Público Federal a iniciativa de se ajuizar uma ação civil pública, quando ele mesmo, como Ministério Público que (também) é, poderia fazê-lo?

A experiência demonstra que a "torre melhor posicionada", que tudo vê, mas não age, e que apenas transfere a responsabilidade de agir, tende a se tornar uma torre vã. Um soldado que flagra uma invasão e só tem poderes para "pedir socorro", quando ele próprio teria plenas condições, e até o dever de agir, tende a ser um praça inútil.

Ressalvando esses recursos metafóricos, o fato é que não pode o MPE combater o desvio e a má-utilização de verbas na Administração Pública, se ele sempre estiver dependente da conveniência de outro Ministério Público para uma solução definitiva.

Seria-lhe extremamente desgastante levantar a bandeira da legalidade e da moralidade, e para isso, ter que enfrentar toda uma ordem cultural já consolidada no erro, se não puder ir, até onde deva, no cumprimento do seu dever ministerial.

Por todas essas elucubrações, chamar um órgão de Ministério Público, dando-lhe previsão constitucional e uma série de atribuições próprias e específicas (procurador geral, corpo de procuradores destacado dos demais Ministérios Públicos, estrutura organizacional, investidura através de concurso público exclusivo para a carreira, autonomia legislativa etc.) e, de conseguinte, reduzir-lhe a uma atuação meramente fiscalizatória, não parece uma lógica das mais razoáveis.

Se ele detém o conhecimento específico sobre a matéria que atua, não pode dedicar esse conhecimento a uma atuação tímida ou burocrática, resignando-se com decisões políticas, ou até teratológicas, que porventura venham a ser ratificadas equivocadamente pelos Tribunais de Contas.

Esta consideração adquire ainda mais força, quando o MPE, em muitos casos, dispõe, no próprio processo administrativo em que atuou, de todos os elementos necessários para justificar uma medida judicial, dispensando até mesmo a instauração de um possível inquérito civil (o que seria necessário para os outros Ministérios Públicos), dada a clarividência dos fatos com que trabalha.

O reconhecimento deste direito que, inclusive, já está posto - aguardando tão-somente a conjugação das diretrizes interpretativas outrora defendidas com esta nova perspectiva para o MPE - dividiria responsabilidades, estabeleceria mais uma legitimidade concorrente, desoneraria o Ministério Público Federal e Estadual, e seria, sem sombra de dúvidas, um reforço importantíssimo às Promotorias e Procuradorias de Defesa do Patrimônio Público, vez que permitiria, uma verdadeira cruzada em favor da legalidade e da moralidade na Administração Pública. Enfim, se ele é Ministério Público, pode agir como tal, basta, apenas, que se reconheça tal condição.

Em artigo de nossa lavra, intitulado Moral e Moralidade Administrativa Aspectos Ontológicos, publicado na RDA $n^{\circ} 228 / 209$, mencionou-se que o princípio da moralidade administrativa deveria ser mais amplo, com mais possibilidades e com menos amarras.

Após uma longa jornada desde a Moral nascida do homem até a moralidade administrativa como princípio constitucional da administração pública, estabeleceu- 
se, na ocasião, o seguinte conceito: "Por todas essas razões, entendo que moralidade administrativa é o princípio que orienta, dentro de um Estado de Direito, o agente a dirigir suas decisões administrativas de forma legítima ao interesse público, fundando-as impreterivelmente na Lei e na Ética Administrativa, esta sim, extraida dos próprios quadros da administração, sem, contudo, olvidar os valores que se estendam da Moral dos homens e tornam-se comuns à Moral Universal e ao Direito Natural, como forma de reconhecer, dentro do serviço público, e como um fator cultural preponderante, o fim maior a ser perseguido de tudo o que é bom e justo" ${ }^{17}$

Não há dúvidas que a efetivação deste conceito vanguardista e abstrato, e que encontra nas malhas filosóficas sua principal acomodação, depende, e muito, de instituições como o MPE. Desde o instante que se reconhece que a busca da plena realização deste princípio é uma responsabilidade de todos os órgãos de controle, não se pode deixar de fora uma instituição estratégica como o Ministério Público Especial, sendo-lhe necessário, ao contrário, dar-lhe todos os meios necessários para que ele faça valer esse princípio em sua dimensão mais verdadeira.

De acrescer, a partir do momento que se reconhece que o Ministério Público junto ao Tribunal de Contas é Ministério Público, como também, que pode agir perante o Judiciário quando tal iniciativa se mostrar imprescindível à defesa da ordem jurídica, passa-se doravante a uma outra perspectiva, qual seja, a de que existe para ele uma legitimação concorrente com o Ministério Público Federal e Estadual, principalmente, nas chamadas ações civis públicas quando o objeto lesado for o patrimônio público.

A Lei $n^{\circ} 7.347 / 85$ (lei da ação civil pública) quando em seu art. $5^{\circ}$ refere-se aos legitimados à propositura da referida medida, não especifica qual o órgão ministerial poderá agir (Ministério Público da União ou dos Estados), menciona, tão-somente, "Ministério Público". Nesse propósito, a doutrina e a jurisprudência são uníssonas ao afirmar que "a legitimação abrange a instituição do MP como um todo, isto é, o MP da União e o MP dos Estados". ${ }^{18}$

Ora, se já foi visto neste estudo que o art.128 não exaure a previsão ministerial — posto que o art. $73, \S 2^{\circ}$, inciso I, c/c o art.130, ambos, da Constituição Federal, prevêem um outro Ministério Público (MPE) - e se, de igual modo, a ação civil pública deve ser reconhecida para a instituição "como um todo", não se pode deixar de reconhecer, também, a legitimidade do MPE para ingressar com tal demanda, quando a sua atuação perante o Tribunal de Contas esbarrar no poder político ou em decisões teratológicas.

O que se quer encampar, é que não pode ele ficar alheio a uma decisão que porventura venha a ratificar o erro e o dolo, fingindo ter cumprido o seu papel de Ministério Público, apenas porque proferiu um parecer contrário àquela situação fática. Se, por exemplo, um determinado agente público deixa de prestar contas,

17 RIBEIRO JUNIOR. Ubergue. Moral e Moralidade Administrativa - Aspectos Ontológicos. Revista de Direito Administrativo n. ${ }^{\circ} 228$, p. 240.

18 NERY JUNIOR, Nelson e NERY, Rosa Maria de Andrade. Código de Processo Civil Comentado. $2^{a}$ edição. São Paulo: Revista dos Tribunais, 1997, p.1.137. 
frauda uma licitação, desvia verbas ou superfatura obras, e o Tribunal, por algum motivo não respaldado na lei (ou precariamente respaldado), deixa de aplicar as medidas de ordem legal, teria o Ministério Público Especial o condão de se resignar com tal decisão?

E mais, seria razoável que ele, que atuou durante todo o processo administrativo e que detém todos os elementos de prova (o que dispensaria inclusive um inquérito civil público), não pudesse ajuizar uma ação civil pública, mesmo sendo, como visto, verdadeiro Ministério Público? Se não possui mais meios para assegurar a ordem jurídica no âmbito de sua atuação originária (Tribunal de Contas), deve se conformar com a consolidação de um fato ilegal ou imoral? Não obstante, se o Ministério Público da União e dos Estados pode dividir a titularidade desta ação com outras entidades (autarquias, fundações, empresas públicas etc.) por que não poderia dividi-la, também, com o Ministério Público Especial?

Com isso, a vertente doutrinária que se quer consolidar nesta obra é que o ponto fundamental para justificar uma medida judicial por parte do MPE não poderá mais ser relacionada à sua legitimidade, mas sim, ao seu interesse de agir, interesse este, que será identificado a partir da experiência casuística.

De qualquer maneira, será o caso concreto, assim como acontece com os demais Ministérios Públicos, que irá definir a atuação do MPE. O que não está certo, é ele ser sumariamente descartado de uma relação jurídica, sob o argumento de sua ilegitimidade, só porque atua, em primeira mão, perante os Tribunais de Contas, como se existisse para si, repise-se, uma exceção ao princípio da inafastabilidade do Poder Judiciário.

É inegável, portanto, que a discussão envolve muito mais aspectos do que estas duas perspectivas referidas, haja vista que várias são as especificidades técnicas e vários são os questionamentos sobre o limite de atuação do Ministério Público junto ao Tribunal de Contas.

À guisa desta constatação, é preciso destacar que esta obra não tem a pretensão de atribuir uma resposta absoluta para um tema tão polêmico, mas sim, mostrar que existe um outro caminho, e que este caminho é perfeitamente viável, ou seja, que existe uma alternativa doutrinária para se chegar à exata natureza jurídica do Parquet Especial, e, a partir dela, se reconhecer que ele pode ser um agente importantíssimo na transformação do seu tempo, a partir de uma ação mais irrestrita e menos burocrática.

\section{7) Conclusão}

Após toda essa árdua peregrinação, embora não seja possível, nesta oportunidade, delinear todos os aspectos argumentados no bojo desta obra, pode-se destacar como dados objetivos, finais e conclusivos deste estudo, os seguintes enunciados:

1) O Ministério Público junto ao Tribunal de Contas, tem natureza jurídica de verdadeiro Ministério Público, encontrando na própria Constituição Federal, sua fonte ontológica e institucional de defesa da ordem jurídica. 
2) Tal natureza ministerial, advém da conjugação do art. $73, \S 2^{\circ}$, inciso $I$, com o art. 130 da Constituição Federal, em interpretação sistemática com o art.127 e 128 do mesmo diploma, fato este, que permite a justaposição do MPE como terceira via ministerial, ao lado, portanto, do Ministério Público da União e dos Estados.

3) Apesar de o art.128 ser omisso em relação ao Ministério Público Especial, a partir do momento que a Constituição Federal prevê em outros dois artigos, (73. $\S 2^{\circ}$, inciso I, e 130 ) a existência de membros de um Ministério Público junto ao Tribunal de Contas, ela passa a contemplar a própria instituição como Ministério Público. Assim, se tal instituição existe, e é fato, e se o art.128 não a prevê como Ministério Público da União ou dos Estados, a conclusão que se chega é a de que ela não pode ser vinculada nem a um nem a outro Ministério Público previsto no art.128, só restando, como se vê, o seu reconhecimento como terceiro gênero.

4) A viabilidade jurídica desta interpretação doutrinária é oriunda de um método dedutivo de análise, aliado a um processo lógico-sistemático que integra uma realidade posta objetivamente na Constituição com os chamados princípios de interpretação constitucional.

5) De todas as teorias estudadas e que procuraram conceder o melhor assento constitucional para o MPE, a posição aqui adotada, que reconhece ao Parquet Especial sua autonomia como órgão do Ministério Público Brasileiro, é a que reúne as melhores condições de harmonia, tanto em relação à norma extraída da Constituição Federal, quanto às próprias funções e objetivos do Ministério Público amplamente considerado.

6) Admitida essa natureza, ou seja, sabendo o que ele efetivamente é, chega-se a conclusão do que pode fazer, e dentro desta perspectiva, apresenta-se como órgão legitimado para se valer do Poder Judiciário, sempre que sua atuação na Corte de Contas esbarrar no poder político e em decisões teratológicas.

\section{Referências bibliográficas}

BRITTO, Carlos Ayres. Ministério Público da União e do Tribunal de Contas Órgãos Distintos. Revista de Direito Público nº 90. (RDP 90/33-44).

CANOTILHO, J.J. Gomes. Direito Constitucional e Teoria da Constituição. $3^{\mathrm{a}}$ edição. Coimbra: Almedina, 1999.

DANTAS, Múcio Villar Ribeiro. O Ministério Público junto aos Tribunais de Contas. Ciência Jurídica, $n^{\circ} 43$, jan/fev, 1992. (Ciência Jurídica 43/321-326).

DEL VECCHIO, Giorgio. Lições de Filosofia do Direito. $5^{\mathrm{a}}$ edição. Coimbra, 1979. FERNANDES, Jorge Ulisses Jacoby. Ministério Público junto aos Tribunais de Contas. Revista de Informação Legislativa, Brasília: Senado Federal, ano $30, \mathrm{n}^{\circ}$ 119, p.233, jul./set.1993.

FRONTINI, Paulo Salvador. Ministério Público, Estado e Constituição. Justitia 90/247. 
GOMES, Augusto. Ministério Público e Tribunais de Contas na Constituição. Revista de Informação Legislativa, Brasília: Senado Federal, ano $30, n^{\circ} 11$, p.227, jul./set.1993.

MAZZILI, Hugo Nigri. O Ministério Público no Tribunal de Contas. RT 650/40.

MORAES, Alexandre de. Constituição do Brasil Interpretada. São Paulo: Atlas, 2002.

Direito Constitucional Administrativo. São Paulo: Atlas, 2002.

NERY JUNIOR, Nelson. Códligo de Processo Civil Comentado. $2^{\mathrm{a}}$ edição. São Paulo: Revista dos Tribunais, 1997.

RÁO, Vicente. O Direito e a Vida dos Direitos. Vol.I $3^{\mathrm{a}}$ edição. São Paulo: Revista dos Tribunais, 1991.

RIBEIRO JUNIOR. Ubergue. Moral e Moralidade Administrativa - Aspectos Ontológicos. Revista de Direito Administrativo $n^{\circ} 228$. (RDA 228/209-242). 


\section{Questões de Direito Positivo}

N. Doreste Baptista,

Renato Maneschy,

Carlos Alberto Direito

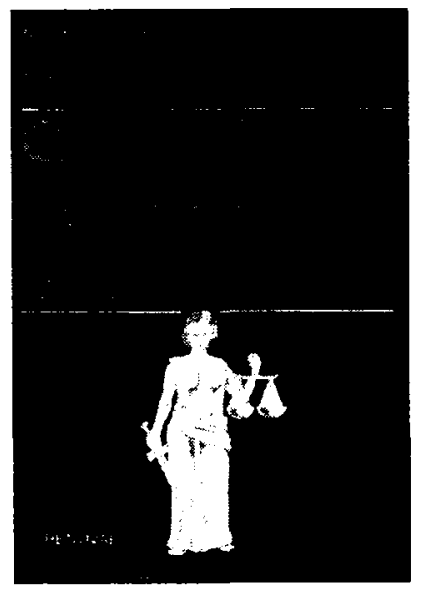

Os autores reuniram acórdāos e votos selecionados de três excelentes julgadores, Desembargadores do Tribunal de Justiça do Estado do Rio de Janeiro, que, inobstante a quantidade exaustiva de processos e trabalhos, conseguem não só manter em dia os serviços, como estudar e produzir soluçōes jurídicas altamente apreciáveis.

Ref. $0018 \quad$ Brochura 330 págs.

Form. 14x21 1990

\section{Reforma das S.A. e do Mercado de Capitais}

Nelson Eizirik

O presente livro apresenta uma análise profunda e detalhada das principais modificações introduzidas em nosso direito societário mediante a reforma da Lei das S.A. e da Lei do Mercado de Capitais. Constitui, pois, indispensável material de consulta para juízes, advogados, estudantes de Direito, assim como para os profissionais que atuam em setores empresariais e no mercado de capitais.

Ref. 0142

Form. 14x21
Brochura

1997
448 págs.

$2^{\text {a }}$ ed.

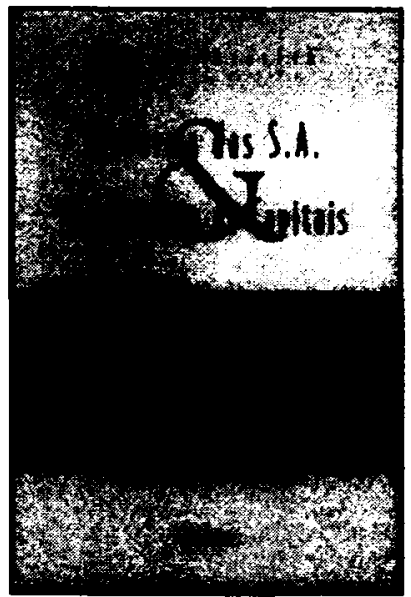

